\title{
Perancangan Aplikasi Penghargaan dan Peningkatan Kinerja Karyawan pada POLSEK Sawah Besar Berbasis Java dengan Metode Simple Additive Weighting (SAW)
}

\author{
Lusi Ariyani \\ Informatika, Universitas Indraprasta, Jakarta, Indonesia \\ e-mail: lusiariyani0312@gmail.com
}

Submitted Date: August $30^{\text {th }}, 2020$

Revised Date: September $23^{\text {rd }}, 2020$
Reviewed Date: September 21 ${ }^{\text {st }}, 2020$

Accepted Date: September $30^{\text {th }}, 2020$

\begin{abstract}
The Indonesian National Police Institution has issued a policy of Chief of Police Regulation Number 16 of 2011 concerning the Civil Servant Performance Assessment System at the National Police with a Performance Management System. In Indonesia, which is competency-based, it is necessary to provide an assessment based on performance standards in an objective, transparent and accountable manner in order to encourage achievement, productivity, dedication and work loyalty. Performance appraisal is a process to measure employee work performance based on work standards that have been set for a certain period. These work standards can be made both qualitatively and quantitatively, one of which can use the SAW method. The definition of the SAW (Simple Additive Weighting) is a way or method to find the weighted sum of the performance ratings in a company or organization. The SAW (Simple Additive Weighting) method is a system used to identify and measure the performance of employees at the National Police so that it is aligned with the organization's vision and mission. The SAW (Simple Additive Weighting) method can be useful in the performance assessment system at the Polsek Sawah Besar because this method has a high level of assessment accuracy.
\end{abstract}

Keywords: Police; Indonesia; SAW; Work Management

\section{Abstrak}

Institusi Kepolisian Republik Indonesia telah mengeluarkan kebijakan Peraturan Kapolri Nomor 16 tahun 2011 berhubungan dengan Sistem Penilaian Kinerja Pegawai Negeri yang bekerja pada institusi Polri. Sebagai bahan pertimbangan terbitnya peraturan ini dalam rangka meningkatkan dan mengembangkan kinerja karyawan yang bekerja di Kepolisian Negara Republik Indonesia. Institusi Kepolisian Indonesia memberikan penilaian sesuai standar kinerja yang transparan, objektif, dan akuntabel. Kebijakan ini berguna untuk mendorong dedikasi, loyalitas, prestasi, produktivitas, dan kerja. Penilaian prestasi kerja merupakan proses mengukur prestasi kerja karyawan sesaui standar pekerjaan selama waktu tertentu yang telah ditetapkan sebelumnya. Peraturan standar kerja tersebut dibuat secara kualitatif dan kuantitatif dapat menggunakan metode tertentu seperti metode SAW. Pengertian metode SAW (Simple Additive Weighting) adalah suatu cara atau metode untuk mencari penjumlahan terbobot dari rating kinerja di suatu perusahaan atau organisasi. Metode Simple Additive Weighting digunakan oleh sistem untuk mengidentifikasi dan mengukur kinerja pegawai Polri sesuai visi dan misi organisasi. Metode SAW (Simple Additive Weighting) dapat berguna dalam sistem penilaian kinerja di Polsek Sawah Besar karna metode ini memiliki tingkat akurasi penilaian yang tinggi.

Kata Kunci: Polisi; Indonesia; SAW; Manajemen Kerja

\section{Pendahuluan}

Kepolisian Negara Republik Indonesia (Polri) merupakan perangkat pemerintahan bidang pemeliharaan ketertiban dan keamanan masyarakat. Kepolisian juga mengemban tugas dalam penegakan hukum, perlindungan, pengayoman, dan pelayanan kepada masyarakat. Kepolisian juga melaksanakan tugas untuk 
membina ketentraman masyarakat dengan mengedapankan hak asasi manusia. Kepolisian mengemban tugas bagian dari tugas negara. Tugas yang dilaksanakan ini tercapai dengan membagi tugas agar mudah dalam pelaksanaan dan juga koordinasi. Organisasi kepolisian dibentuk dengan tujuan memberikan perlindungan kepada masyarakat dari ancaman orang yang tidak bertanggung jawab melakukan tindakan pidana atau melanggar peraturan hukum yang berlaku. Peraturan yang digunakan sebagai pedoman pelaksanaan tugas kepolisian agar berjalan dengan baik dan dapat dipatuhi (Prakoso, 2013).

Institusi Kepolisian Republik Indonesia telah mengeluarkan kebijakan Peraturan Kapolri Nomor 16 tahun 2011 berhubungan dengan Sistem Penilaian Kinerja Pegawai Negeri yang bekerja pada institusi Polri. Sebagai bahan pertimbangan terbitnya peraturan ini dalam rangka meningkatkan dan mengembangkan kinerja karyawan yang bekerja di Kepolisian Negara Republik Indonesia. Institusi Kepolisian Indonesia memberikan penilaian sesuai standar kinerja yang transparan, objektif, dan akuntabel. Kebijakan ini berguna untuk mendorong dedikasi, loyalitas, prestasi, produktivitas, dan kerja. Penilaian prestasi kerja adalah suatu proses untuk mengukur prestasi kerja pegawai berdasarkan standar pekerjaan yang telah ditetapkan selama periode tertentu, Sedarmayanti, (2017:38). Standar kerja tersebut dapat dibuat baik secara kualitatif maupun kuantitatif salah satunya dapat menggunakan metode SAW, Fishburn (2015:35), pengertian metode SAW (Simple Additive Weighting) adalah suatu cara atau metode untuk mencari penjumlahan terbobot dari rating kinerja di suatu perusahaan atau organisasi. Metode Simple Additive Weighting digunakan oleh sistem untuk mengidentifikasi dan mengukur kinerja pegawai Polri sesuai visi dan misi organisasi. Metode SAW (Simple Additive Weighting) dapat berguna dalam sistem penialaian kinerja di Polsek Sawah Besar karena metode ini memiliki tingkat akurasi penilaian yang tinggi.

Di Polsek Sawah Besar saat ini melakukan sistem penilaian kinerja karyawan secara manual. Cara kerja sistem seperti ini membutuhkan waktu dalam pengolahan data sehingga menjadi kurang efektif dan efisien. Penggunaan kertas yang tidak efisien berdampak pada hilangnya kertas yang berisi data tentang penilaian kinerja karyawan. Sehingga apabila terjadi kehilangan, maka harus dilakukan lagi pengambilan penilaian, hal ini banyak memakan waktu yang lebih lama. Adapun kekurangan penggunaan kertas ialah membutuhkan tempat penyimpanan yang lebih besar.

Berdasarkan berbagai permasalahan di atas, dapat disimpulkan bahwa dibutuhkan suatu sistem terkait penilaian kinerja karyawan yang efektif, efisien dan akurat. Oleh sebab itu penulis tertarik untuk membuat suatu aplikasi yang sesuai dengan kebutuhan di Polsek Sawah Besar dan penelitian ini penulis beri judul "Perancangan Aplikasi Penghargaan Dan Peningkatan Kinerja Karyawan Pada Polsek Sawah Besar Berbasis Java Dengan Metode Simple Additive Weighting (SAW)".

\section{Metodologi}

Polsek Sawah Besar yang beralamat di Jalan Dr. Wahidin Raya No. 8, Pasar Baru, Kecamatan Sawah Besar, Jakarta Pusat dipimpin oleh Kompol Eliantoro Jasmaf. Memiliki beberapa unit kerja yaitu Reskrim, Sabhara, dan Binmas dengan tujuan untuk menjaga keamanan, ketertiban masyarakat, menegakkan hukum, memberikan perlindungan, kelancaran lalu lintas, mengajak masyarakat dalam partisipasi kegiatan, memngajak kesadaran hukum supaya warga masyarakat taat terhadap hukum juga peraturan perundang-undangan. Polri mengajak masyarakat menjaga ketertiban juga menjamin keamanan umum. Polri bertaanggung jawab dan melindungi keselamatan jiwa raga, harta benda, masyarakat, dan lingkungan terhadap gangguan ketertiban dan bencana. Tugas lain Polri memberikan bantuan dengan menghormati hak asasi manusia. Yang selanjutnya unit kerja Polri berfokus kepada masyarakat yaitu melayani kepentingan warga masyarakat dalam lingkup tugas kepolisian.

\subsection{Proses Bisnis}

Proses bisnis merupakan kumpulan aktifitas atau pekerjaan terstruktur saling terkait untuk menyelesaikan suatu masalah. Sistem informasi penilaian penghargaan dan peningkatan kinerja karyawan di Polsek Sawah Besar terbilang sederhana, masih dilakukan secara manual, kemungkinan akan terjadi kesalahan atau kehilangan data secara permanen. Data penilaian kinerja yang sudah dinilai disimpan di atas meja tidak menutup kemungkinan akan hilang dan bahkan juga bisa dicuri oleh orang lain atau rekan kerja di dalam kantor. Bagaimana sistem bekerja atau diproses dari sistem ini adalah:

1. Pembuatan Form Penilaian Kinerja Karyawan 
Proses pembuatan form ini dilakukan oleh tata usaha dengan periode penilaian setiap setahun sekali.

2. Penilaian Kinerja Karyawan

Proses pengisian penilaian kinerja karyawan di Polsek Sawah Besar dilakukan oleh Kepala Kepolisian Sektor Sawah Besar.

3. Pembuatan Laporan

Proses pembuatan laporan dilakukan oleh tata usaha. Setelah itu tata usaha akan memberikan laporan kepada Kepala Kepolisian Sektor Sawah Besar.

Setelah lembaran-lembaran kertas penilaian kinerja karyawan sudah dinilai oleh Kepala Kepolisian Sektor Sawah Besar maka proses pengarsipan laporan dilakukan oleh tata usaha di ruang khusus penyimpanan data arsip. Proses bisnis yang diusulkan adalah dengan mengubah sistem manual menjadi sistem terkomputerisasi sehingga data penilaian lebih aman dan penilaian kinerja karyawan menjadi efektif serta efisien. Proses bisnis yang diusulkan adalah:

1. Form Penilaian Kinerja Karyawan

Proses pembuatan form ini dilakukan oleh tata usaha di aplikasi penghargaan dan peningkatan kinerja karyawan, dengan periode penilaian setiap setahun sekali.Penilaian Kinerja Karyawan

2. Proses pengisian penilaian kinerja karyawan di Polsek Sawah Besar dilakukan oleh Kepala Kepolisian Sektor Sawah Besar dengan menggunakan aplikasi penghargaan dan peningkatan kinerja karyawan.

3. Pembuatan Laporan

Laporan dapat langsung dicetak oleh tata usaha maupun disimpan karna saat pengisian penilaian di aplikasi penghargaan dan peningkatan kinerja karyawan nilai sudah otomatis masuk ke dalam database.

\subsection{Aturan Bisnis}

Berdasarkan keterbatasan sistem penilaian kinerja karyawan, aturan bisnis maupun kebijakan pada sistem yang berjalan di Polsek Sawah Besar adalah selama satu periode karyawan dapat memenuhi kehadiran dan melakukan pelayanan masyarakat dan dihitung menggunakan sistem manajemen kinerja karyawan. Pada form penilaian kinerja karyawan aturan bisnis yang berjalan adalah form penilaian dibuat oleh tata usaha. Maka penulis mencoba mengusulkan suatu aturan bisnis yang dapat mempermudah pekerjaan tata usaha dalam melakukan penilaian kinerja karyawan yaitu dengan membuat suatu sistem aplikasi penghargaan dan peningkatan kinerja karyawan dengan menggunakan metode SAW yang dapat menjembatani keterbatasanketerbatasan tersebut.

Metode SAW biasanya diidentikan dengan metode penjumlahan terbobot. Dasar konsep dari metode ini adalah mencari penjumlahan terbobot rating kinerja di masing-masing alternatif sejumlah atribut. Banyak teknik pengambilan keputusan menggunakan Metode SAW, namun cara kerja dari metode ini adalah hanya menghasilkan nilai terbesar sebagai alternatif terbaik. Metode ini bekarja apabila alternatif terpilih memebuhi kriteria dalam perhitungan. Normalisasi Matriks keputusan (x) adalah proses yang dibutuhkan dalam metode ini, untuk mencari skala dari semua nilai alternatif yang ada. Metode SAW ini dipilih dalam pembuatan aplikasi untuk menentukan keputusan yang mendapat penghargaan sebagai karyawan terbaik.

Table terbentuk menjadi 4 yang berisi variabel kriteria yang diperoleh dari hasil wawancara yaitu tanggung jawab, sikap, kemampuan, dan kecepatan. Berikut ini adalah table table hasil analisa data:

Tabel 1 Kriteria dan Bobot Tanggung Jawab (C1)

\begin{tabular}{|c|c|}
\hline Tanggung Jawab & Nilai (Bobot) \\
\hline A & 5 \\
\hline B & 4 \\
\hline C & 3 \\
\hline D & 2 \\
\hline E & 1 \\
\hline
\end{tabular}

Tabel 2 Kriteria dan Bobot Sikap (C2)

\begin{tabular}{|c|c|}
\hline Sikap & Nilai (Bobot) \\
\hline A & 5 \\
\hline B & 4 \\
\hline C & 3 \\
\hline D & 2 \\
\hline E & 1 \\
\hline
\end{tabular}

Tabel 3 Kriteria dan Bobot Kemampuan (C3)

\begin{tabular}{|c|c|}
\hline Kemampuan & Nilai (Bobot) \\
\hline A & 5 \\
\hline B & 4 \\
\hline C & 3 \\
\hline D & 2 \\
\hline E & 1 \\
\hline
\end{tabular}

Tabel 4. Kriteria dan Bobot Kecepatan (C4)

\begin{tabular}{|c|c|}
\hline Kecepatan & Nilai (Bobot) \\
\hline A & 5 \\
\hline B & 4 \\
\hline C & 3 \\
\hline D & 2 \\
\hline E & 1 \\
\hline
\end{tabular}


Tabel 5 Contoh Kasus

\begin{tabular}{|l|c|c|c|c|}
\hline $\begin{array}{c}\text { Nama } \\
\text { Karyawan }\end{array}$ & $\begin{array}{c}\text { Tanggung } \\
\text { Jawab }\end{array}$ & Sikap & Mampu & Cepat \\
\hline Ika Marko & B & B & B & B \\
\hline $\begin{array}{l}\text { Ade } \\
\text { Chandra }\end{array}$ & B & B & C & B \\
\hline Nyoman & A & B & A & A \\
\hline Hariyanto & A & D & B & A \\
\hline
\end{tabular}

Tabel 6 Rating Kecocokan Setiap Alternatif pada kriteria

\begin{tabular}{|c|c|c|c|c|}
\hline Nama & \multicolumn{4}{|c|}{} \\
\cline { 2 - 5 } Karyawan & $\begin{array}{c}\text { Tanggung } \\
\text { Jawab }\end{array}$ & Sikap & Mampu & Cepat \\
\hline A1 & 4 & 4 & 4 & 4 \\
\hline A2 & 4 & 4 & 3 & 4 \\
\hline A3 & 5 & 4 & 5 & 5 \\
\hline A4 & 5 & 2 & 4 & 5 \\
\hline Bobot & 40 & 30 & 30 & 30 \\
\hline
\end{tabular}

Selanjutnya mencari alternatif terbaik menggunakan persamaan:

$$
\mathrm{R}=\begin{gathered}
x(x i j) \\
\operatorname{Max}(x i j)
\end{gathered}
$$

Keterangan:

Max $(x i j)=$ mencari nilai terbesar dari himpunan $\mathrm{x}$

Maka dari tabel 6 penilaian kinerja karyawan tertinggi adalah:

$$
\begin{array}{ll}
\mathrm{R} 11=\frac{4}{\operatorname{Max}(4 ; 4 ; 5 ; 5)}=\frac{4}{5}=0.8 \\
\mathrm{R} 21=\frac{4}{\operatorname{Max}(4 ; 4 ; 5 ; 5)}=\frac{4}{5}=0.6 \\
\mathrm{R} 31=\frac{5}{\operatorname{Max}(4 ; 4 ; 5 ; 5)}=\frac{5}{5}=1 \\
\mathrm{R} 41=\frac{5}{\operatorname{Max}(4 ; 4 ; 5 ; 5)}=\frac{5}{5}=1 \\
\mathrm{R} 12=\frac{4}{\operatorname{Max}(4 ; 4 ; 4 ; 2)}=\frac{4}{4}=1
\end{array}
$$

$$
\begin{aligned}
& \text { R22 }=\frac{4}{\operatorname{Max}(4 ; 4 ; 4 ; 2)}=\frac{4}{4}=1 \\
& \mathrm{R} 32=\frac{4}{\operatorname{Max}(4 ; 4 ; 4 ; 2)}=\frac{4}{4}=1 \\
& \mathrm{R} 42=\frac{2}{\operatorname{Max}(4 ; 4 ; 4 ; 2)}=\frac{2}{4}=0.5 \\
& \mathrm{R} 13=\frac{4}{\operatorname{Max}(4 ; 3 ; 5 ; 4)}=\frac{4}{5}=0.8 \\
& \mathrm{R} 23=\frac{3}{\operatorname{Max}(4 ; 3 ; 5 ; 4)}=\frac{3}{5}=0.6 \\
& \mathrm{R} 33=\frac{5}{\operatorname{Max}(4 ; 3 ; 5 ; 4)}=\frac{5}{5}=1 \\
& \mathrm{R} 43=\underset{\operatorname{Max}(4 ; 3 ; 5 ; 4)}{4}=\frac{4}{5}=0.8 \\
& \mathrm{R} 13=\frac{4}{\operatorname{Max}(4 ; 4 ; 5 ; 5)}=\frac{4}{5}=0.8 \\
& \mathrm{R} 23=\frac{4}{\operatorname{Max}(4 ; 4 ; 5 ; 5)}=\frac{4}{5}=0.8 \\
& \text { R33 }=\frac{5}{\operatorname{Max}(4 ; 4 ; 5 ; 5)}=\frac{5}{5}=1 \\
& \mathrm{R} 43=\frac{5}{\operatorname{Max}(4 ; 4 ; 5 ; 5)}=\frac{5}{5}=1
\end{aligned}
$$

Perolehan nilai tertingginya: V1

$$
\begin{array}{lll}
\text { V1 } & =0.8+1+0.8+0.8 & =3.4 \\
\text { V2 } & =0.6+1+0.6+0.23 & =2.4 \\
\text { V3 } & =1+1+1+1 & =4.0 \\
\text { V4 } & =1+0.5+0.8+1 & =3.3
\end{array}
$$

Nilai tertinggi adalah V3 (Nyoman).

Untuk bisa mengakses metode SAW dalam aplikasi pengguna melakukan login yaitu memasukan username dan password di halaman form login aplikasi. Hal ini dimaksudkan untuk membatasi akses informasi penilaian kinerja karyawan hanya kepada tata usaha dan Kepala Kepolisian Sektor Sawah Besar sehingga kerahasiaan data tetap terjaga. Berikut ini adalah aturan dan kebijakan- kebijakan sistem yang terdapat di aplikasi penghargaan dan peningkatan 
kinerja karyawan yang dibuat peneliti, di antaranya:

1. Tata usaha dan Kepala Kepolisian Sektor Sawah Besar dapat mengakses halaman informasi yang terdapat di dalam aplikasi, kemudian login dengan mengisikan username dan password.

2. Kemudian tata usaha dapat membuat maupun mengedit data karyawan, data penilaian beserta bobot dan kriteria dari setiap penilaian karyawan.

3. Kepala Kepolisian Sektor Sawah Besar memberikan nilai dari setiap karyawan.

4. Hasil dari penilaian berupa laporan dicetak dan diberikan kepada Kepala Kepolisian Sektor Sawah Besar dan data penilaian kinerja karyawan otomatis tersimpan di dalam database.

\subsection{Dekomposisi Fungsi}

Dekomposisi fungsi dimaksudkan untuk mengetahui gambaran fungsi- fungsi proses dan bentuk masukan serta keluaran yang terdapat pada sistem yang dijalankan. Berikut ini gambaran dari dekomposisi fungsi sistem:

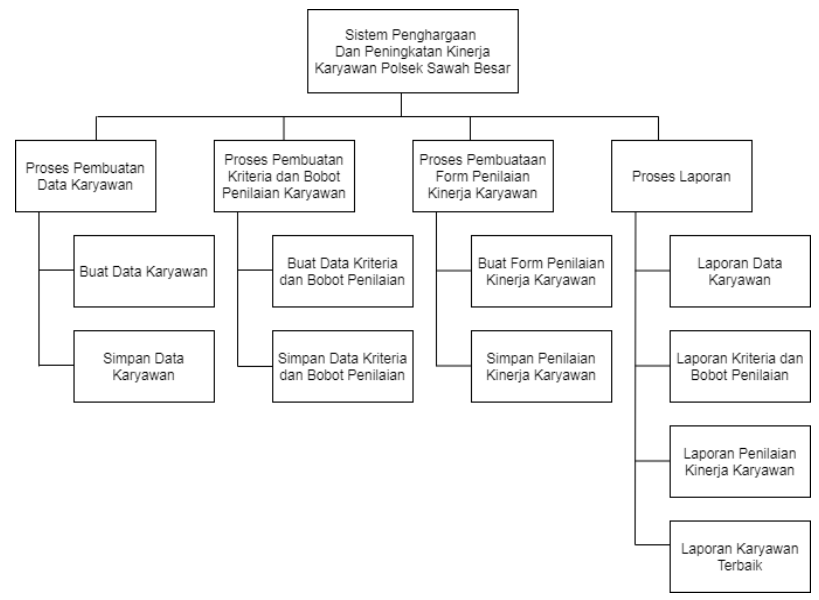

Gambar 1 Dekomposisi Fungsi

\subsection{Diagram Aliran Data}

Diagram ini menjelaskan suatu system yang digambarkan dengan lingkaran yang merupakan lambang proses dan beberpa terminator atau elemen dari sistem. Digram ini merupakan bagian dari diagram DAD yang memiliki level tertinggi. Diagram dapat menjelaskan gambaran masukan dan keluaran dari sistem secara keseluruhan.

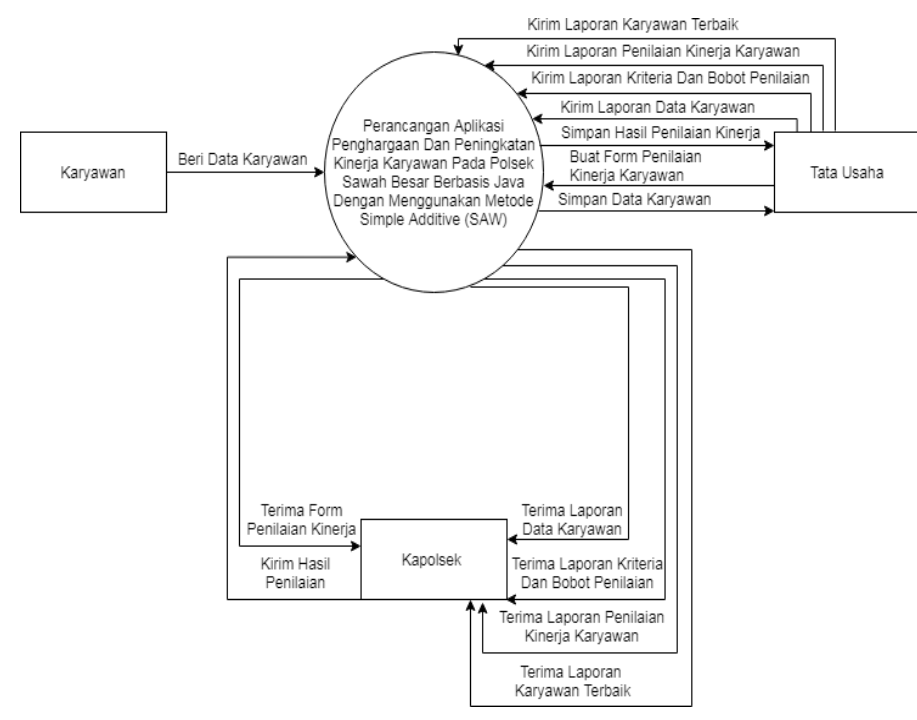

Gambar 2 Diagram Konteks

\subsection{Analisa Basis Data}

Diagram Entity relationship permodelan yang menjelaskan data konseptual dalam bentuk notasi grafis yang menggambarkan hubungan antar data selama penyimpan. Berikut ini adalah gambaran diagram ER dalam aplikasi penghargaan dan peningkatan kinerja karyawan yaitu:

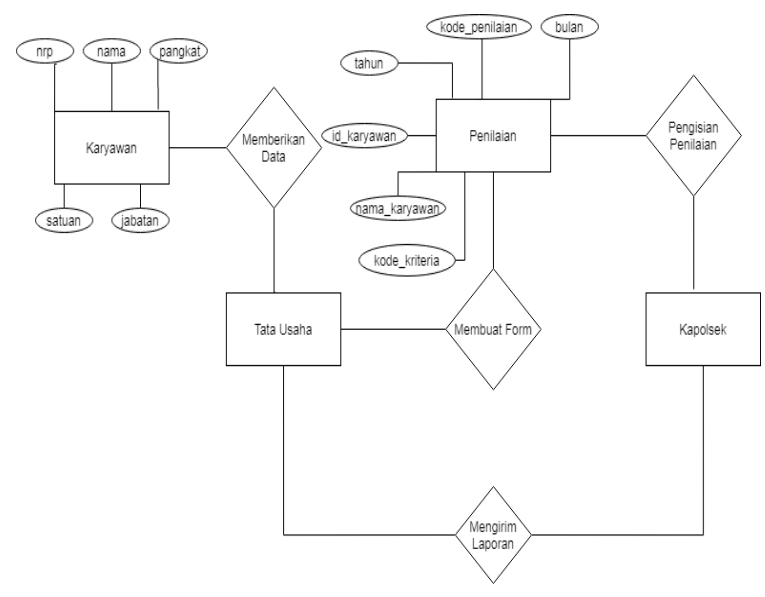

Gambar 3. Entity Relationship Diagram

\section{Implementasi dan Pembahasan}

Tampilan ini muncul pada saat pertama kali pengoperasian aplikasi penghargaan dan peningkatan kinerja karyawan pada Polsek Sawah Besar. Pada halaman ini pengguna mengisi username dan password yang sesuai. 


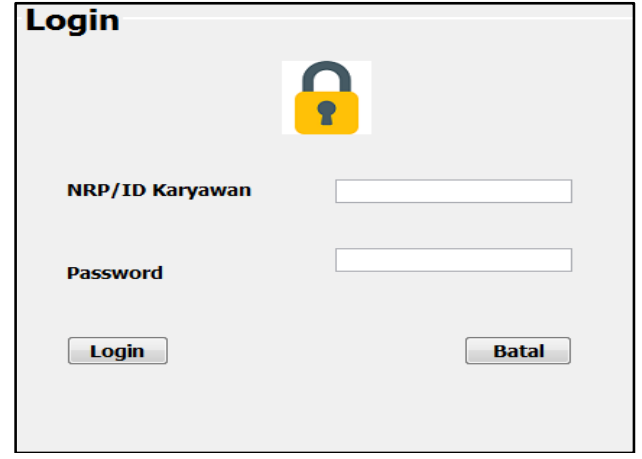

Gambar 4. Tampilan Layar Login

Tampilan ini muncul pada saat setelah menu admin di pilih, maka muncul pilihan data admin, ganti password dan logout. Data user dan password tidak boleh salah memasukkan.

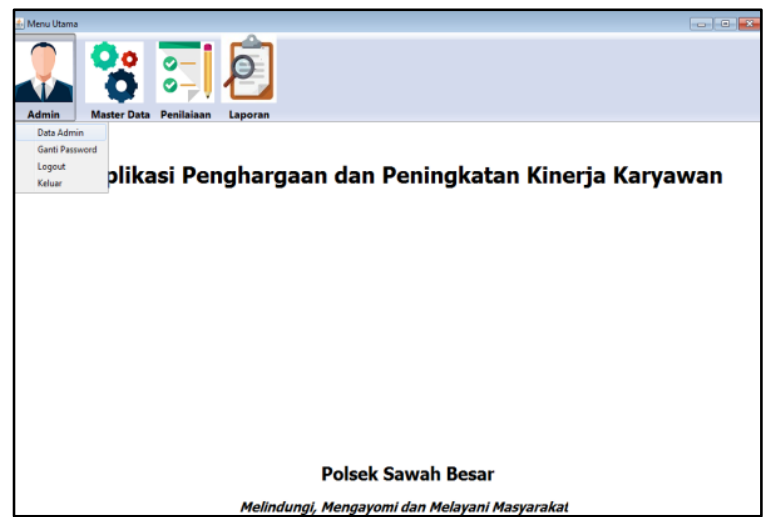

Gambar 5 Tampilan Layar Admin

Tampilan muncul pada saat setelah menu data admin di pilih, maka muncul tampilan yang berisi tentang data-data admin sepert id, nama, jabatan, dan password. Data yang muncul sesuai dengan login akun masing-masing.

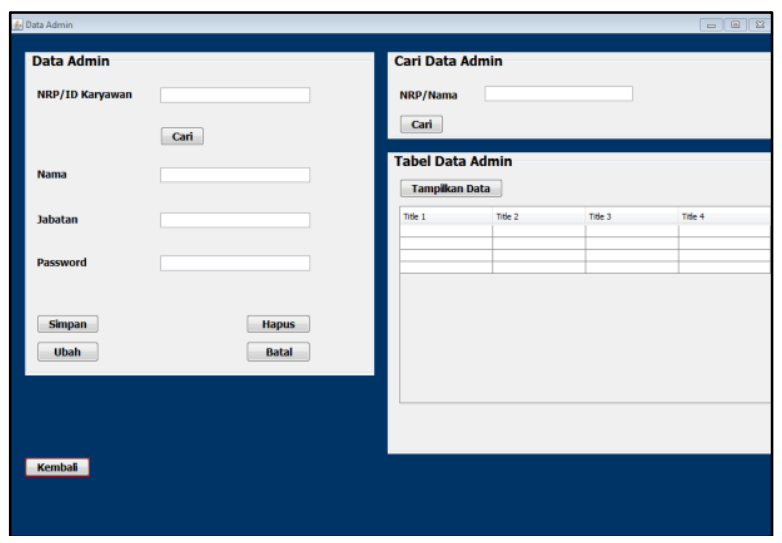

Gambar 6. Tampilan Form Masukan Admin
Tampilan ini muncul pada saat setelah menu master data di klik, maka muncul tampilan yang berisi data anggota Porli, karyawan, kriteria dan bobot. Data pegawai tersebut sebelumya sudah tersimpan di database sistem.

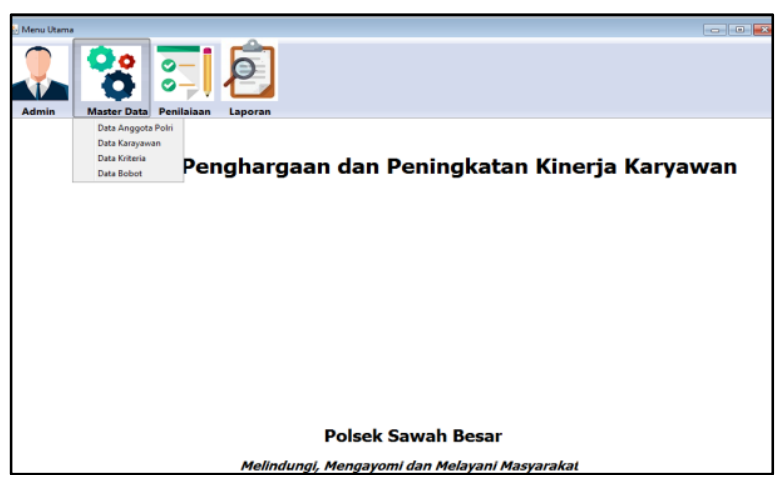

Gambar 7. Tampilan Layar Master Data

Tampilan ini muncul pada saat setelah data anggota Polri di pilih, maka muncul tampilan yang berisi data anggota Porli yaitu nrp, nama, pangkat, jabatan, satuan. Data detail pegawai sesuai dengan yang dipilih untuk ditampilkan secara detail.

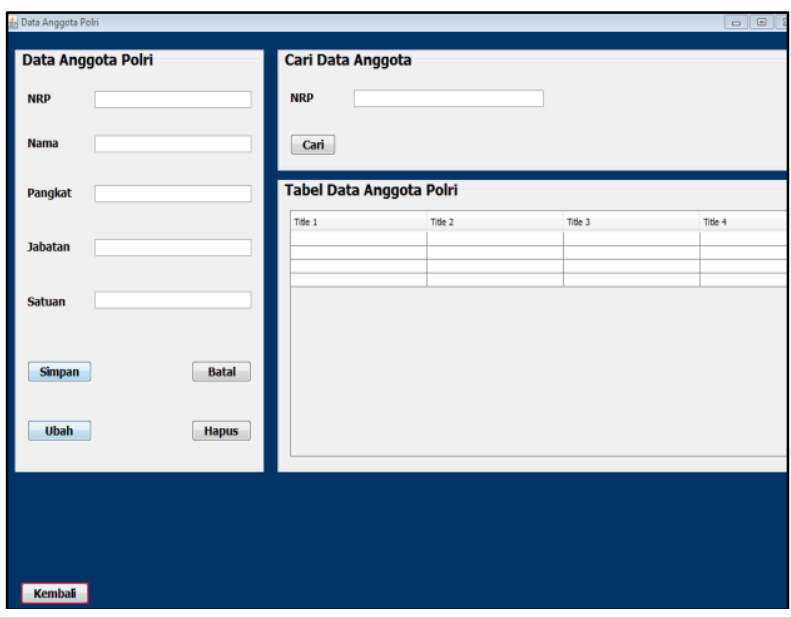

Gambar 8. Tampilan Form Masukan Data Anggota Polri

Tampilan ini berisikan data form penilaian yaitu kode penilaian, nrp, nama, kode kriteria, nama kriteria, penilaian dan dilengkapi dengan tombol simpan, ubah, batal, hapus, tampil data, kembali dan cetak. Data yang di tampilkan merupakan data pendukung untuk penilaian. 


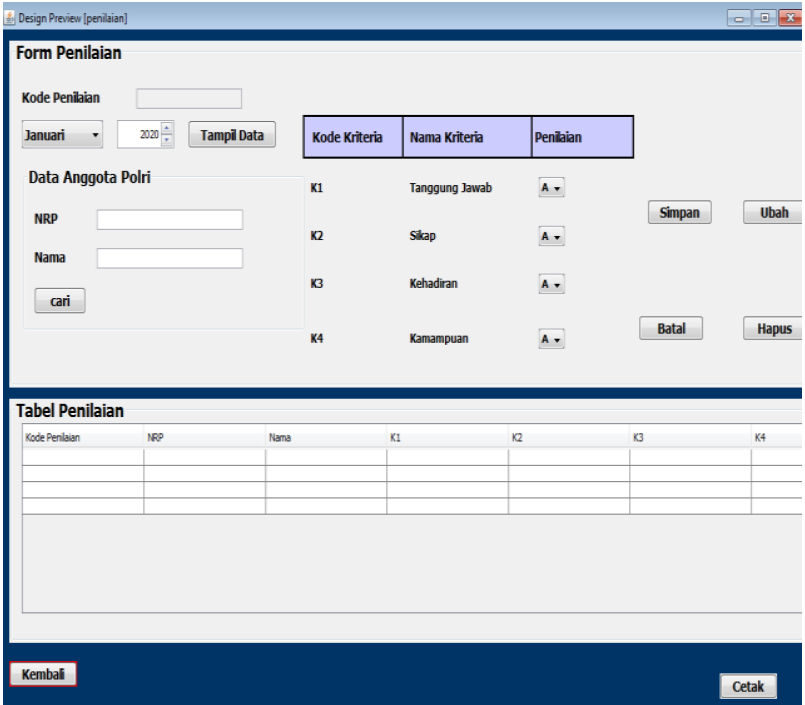

Gambar 9. Tampilan Form Masukan Penilaian

Tampilan ini menampilkan periode, kode panilaian, id penilaian, nama, dan nilai dari setiap kriteria. Data kriteria tersebut menjadi perhitungan dalam penilaian.

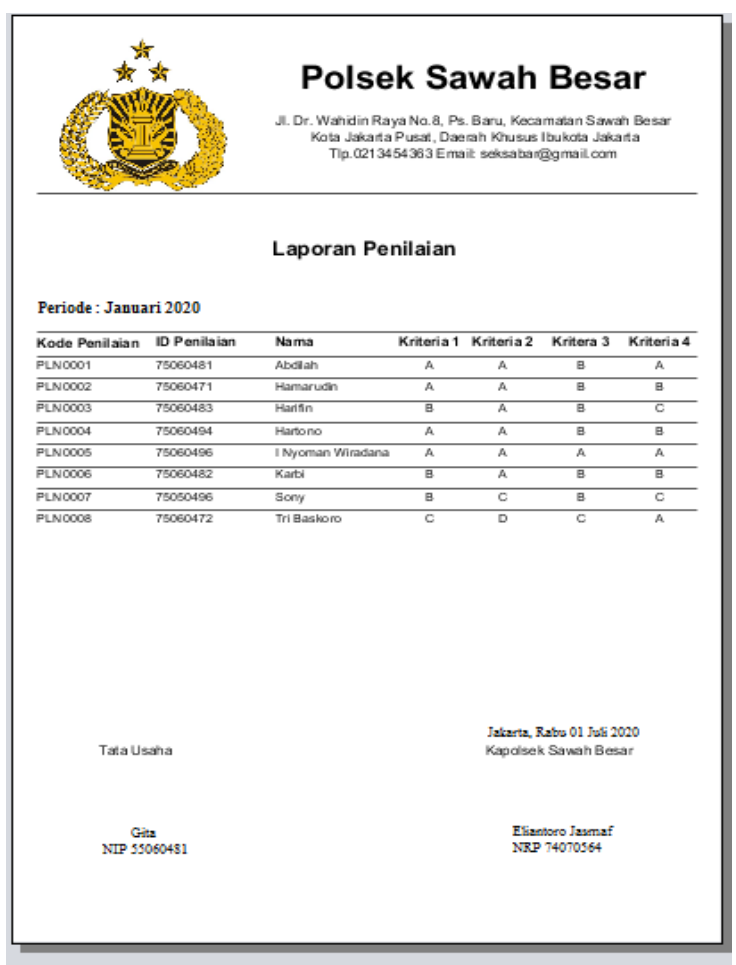

Gambar 10. Tampilan Keluaran Laporan Penilaian

Tampilan ini menampilkan periode, peringkat dari yang tertinggi, kode penilaian, nama dan nilai akhir. Nilai tertinggi menjadi acuan sebagai nilai pegawai terbaik.

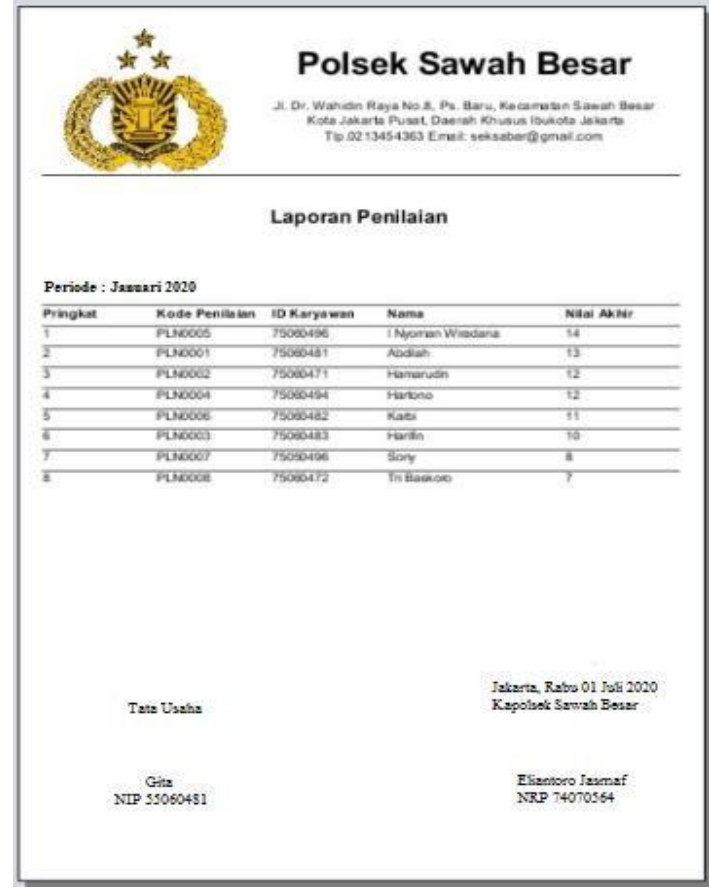

Gambar 11. Tampilan Keluaran Laporan Perankingan

Tampilan ini menampilkan data karyawan seperti id karyawan, nama, jenis kelamin, jabatan, no telp dan alamat. Data laporan tersebut menjelaksan data pegawai tebaik.

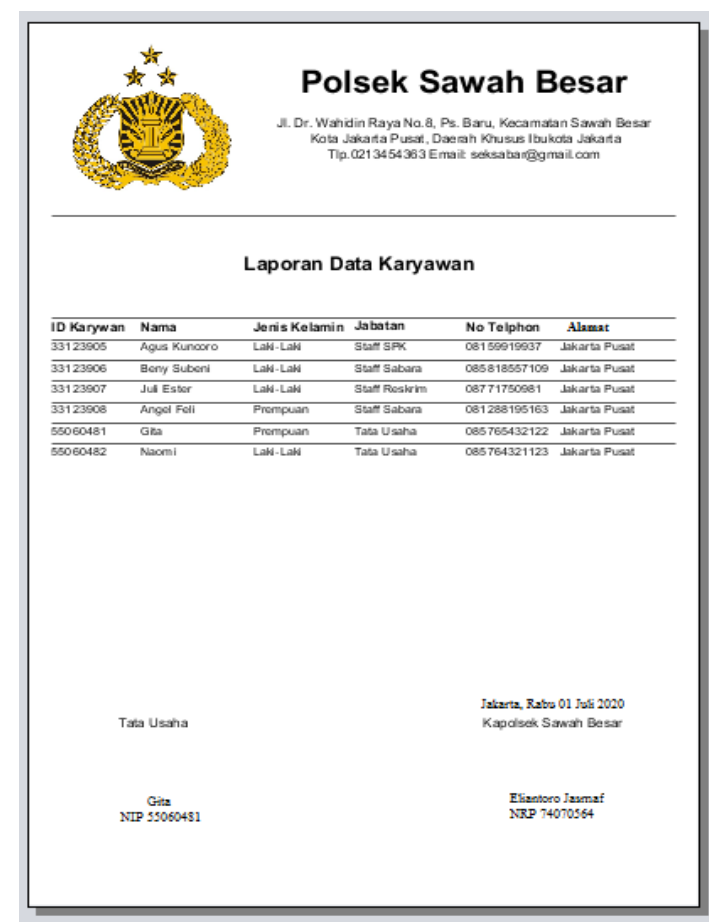

Gambar 12. Tampilan Keluaran Laporan Karyawan 
Tampilan ini menampilkan periode, kode penilaian, nama, nilai akhir dan nilai dari setiap kriteria. Data kriteria menjadi data penilaian pegawai terbaik.

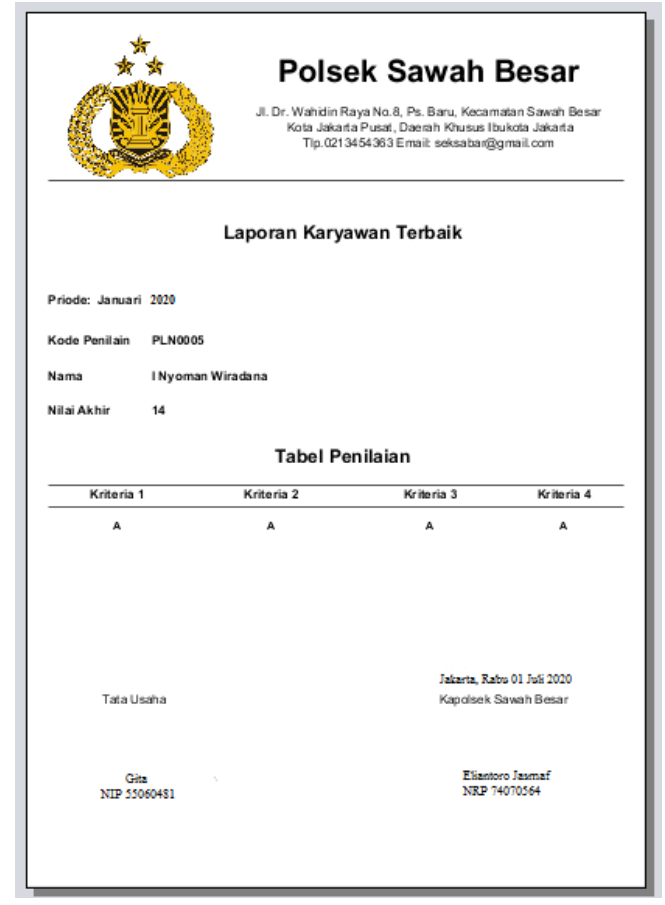

Gambar 13 Tampilan Keluaran Laporan Karyawan Terbaik

\section{Simpulan}

Hasil pembahasan dalam diuraikan pada bagian sebelumnya maka kesimpulan sebagai berikut:

1. Dengan dibangunnya aplikasi penghargaan dan peningkatan kinerja karyawan pada Polsek Sawah Besar diharapkan dalam proses pengambilan keputusan terkait penilaian karyawan dapat berjalan lebih efektif dan efisien.

2. Dengan adanya aplikasi penghargaan dan peningkatan kinerja karyawan pada Polsek Sawah Besar dapat mengurangi biaya dalam hal mencetak kertas form penilaian dan meminimalkan pengeluaran karna tidak membutuhkan ruang penyimpanan yang besar.

3. Setelah dibuatnya aplikasi penghargaan dan peningkatan kinerja karyawan pada Polsek Sawah Besar ini, data yang tersimpan dalam sistem sudah terotomatis di database. Sehingga dapat meminimalisir kerusakan atau kehilangan data.

\section{Saran}

Berikut ini adalah beberapa saran dan solusi yang ditujukan untuk menyelesaikan permasalahan:

1. Proses sistem penilaian kinerja karyawan pada Polsek Sawah Besar selama ini masih menggunakan lembar form kertas dapat menggunakan sistem komputerisasi untuk lebih efektif dan efisien.

2. Rancang bangun penghargaan dan peningkatan kinerja karyawan pada Polsek Sawah Besar menggunakan aplikasi sederhana. Aplikasi ini dapat di tingkatkan dengan cara menambah beberapa fitur seperti penggunaan aplikasi multiuser sehingga pengguna dapat memasukan data masing-masing.

3. Adanya kekurangan dalam penelitian ini kiranya dapat diperbaiki dan disempurnakan dengan memperhatikan tampilan yang lebih mudah bagi para pengguna.

\section{Referensi}

Andi, P. d. (2012). Analisis Perbandingan Trading Volume. Surakarta: Aksarra Sinergi Media.

Fishburn. (2015). Konsep dan Aplikasi Sistem Pendukung Keputusan. Yogyakarta: Andi.

Kapolri. (2015, Februari 29-Februari-2019). Penilaian Kinerja Bagi Pegawai Negeri Pada Polri Dengan Sistem Manajemen Kinerja. Retrieved from peraturan kapolri: https://www.peraturankapolri.com/2015/10/pe raturan-kapolri- nomor-16-tahun-2011.html

Prakoso, A. (2013). Kriminologi dan Hukum Pidana. Yogyakarta: Laksbang Grafika.

Purnomo. (2012). Dasar-Dasar Penggunaan Microsoft Office. Jakarta: CV Infomedika.

Sedarmayanti. (2017). Sumber Daya Manusia dan Produktivitas Kerja. Bandung: CV Mandar Maju.

Sujatmiko. (2016). Perancangan Sistem. Surakarta: Aksarra Sinergi Media.

Sujatmiko, E. d. (2012). Kamus Teknologi Informasi dan Komunikasi. Surakarta: Aksarra Sinergi Media.

Susilana, R. d. (2018). Media Pembelajaran Teknologi. Bandung: Wacana Prima.

Tata, S. (2012). Analisis Sistem Informasi. Jogjakarta: Andi. 